\title{
PENGARUH PENGGUNAAN MADU TERHADAP NILAI pH, SINERESIS, DAN TOTAL BAKTERI ASAM LAKTAT YOGHURT SINBIOTIK
}

\author{
Reynaldi Baguna, A. Yelnetty*, S.E. Siswosubroto, N. Lontaan \\ Fakultas Peternakan Universitas Sam Ratulangi Manado. 95115
}

\begin{abstract}
ABSTRAK
Penelitian dilakukan untuk mengetahui apakah madu memberi pengaruh terhadap nilai $\mathrm{pH}$, sineresis dan BAL yoghurt sinbiotik. Pada penelitian ini bahan utama yang digunakan adalah susu UHT 4 L, skim milk $400 \mathrm{~g}$, madu $240 \mathrm{~mL}$, Bakteri Asam Laktat (BAL) Lactobacillus acidophillus, Streptococcus thermophilus dan Lactobacillus bulgaricus, aqudes, Media MRS (Man Rogosa Sharpe Medium). Peralatan yang digunakan selama penelitian antara lain autoclave, $\mathrm{pH}$ meter, Erlenmeyer, tabung reaksi, pipet, thermometer, timbangan analitik, cawan petri, desikator, blender, oven, incubator, pipet mikro, buret, lampu spritus, gelas piala, lemari pendingin. Penelitian ini telah dilaksanakan pada tanggal 7 Januari 2019 sampai dengan 12 Maret 2019 di Laboratorium Teknologi Hasil Ternak Fakultas Peternakan Universitas Sam Ratulangi Manado. Rancangan percobaan yang digunakan pada penelitian ini adalah metode Rancangan Acak Lengkap (RAL) dengan 5 perlakuan dan 4 ulangan, variabel yang diukur pada penelitian ini yaitu nilai $\mathrm{pH}$, Sinereis dan Total BAL. Data yang diperoleh dianalisis menggunakan ANOVA, ada perbedaan nyata antara perlakuan dilanjutkan dengan uji BNJ. Hasil penelitian ini menunjukkan bahwa perlakuan $(0 \%),(3 \%),(6 \%),(9 \%)$ dan (12\%) memberikan pengaruh yang berbeda sangat nyata $(\mathrm{P}<0,01)$ terhadap nilai $\mathrm{pH}$, Sineresis dan Total BAL.
\end{abstract}

*Korespondensi (corresponding author) Email: ayelnetty@unsrat.ac.id
Berdasarkan hasil dan pembahasan bahwa dengan penggunaan madu sebesar $12 \%$ dapat meningkatkan nilai serta menghasilkan $\mathrm{pH}$, sineresis dan total bakteri asam laktat terbaik pada yoghurt sinbiotik.

Kata Kunci : Yoghurt Sinbiotik, Madu, $\mathrm{pH}$, Sinresis, BAL.

\section{ABSTRACT}

THE EFFECT OF THE ADDITION OF HONEY TO THE PH VALUE, SYNERESIS AND TOTAL LACTIC ACID BACTERIA OF SINBIOTIK YOGURT. This study was conducted to determine whether honey gives an influence on the $\mathrm{pH}$ value, syneresis and LAB of synbiotic yogurt. In this study, the main ingredients used were 5 liters UHT milk, Skim milk $400 \mathrm{~g}$, honey $240 \mathrm{~mL}$, Lactobacillus acidophillus bacteria, Streptococcus thermophilus and Lactobacillus bulgaricus, aqudes, MRS Media (Man Rogosa Sharpe Medium). Equipment used during the study included autoclave, $\mathrm{pH}$ meter, Erlenmeyer, test tube, pipette, thermometer, analytical scale, petri dishe, desiccator, blender, oven, incubator, micro pipette, burette, spritus lamp, goblet, refrigerator. This research was carried out on January 72019 until March 122019 at the Laboratory of Animal Product Technology Faculty of Animal Husbandry, Sam Ratulangi University, Manado. The experimental design used in this study was a Completely Randomized Design (CRD) method with treatments 5 and 4 
replications. The variables analyzed in this study are $\mathrm{pH}$, Sinereis and Total LAB. The data obtained were analyzed using ANOVA, there were significant differences between the treatments followed by the BNJ test. The results of this study indicate that the treatments of $\mathrm{P} 0(0 \%), \mathrm{P} 1(3 \%)$, $\mathrm{P} 2(6 \%), \mathrm{P} 3(9 \%)$ and $\mathrm{P} 4(12 \%)$ have a very significant effect $(\mathrm{P}<0.01)$ on the $\mathrm{pH}$ value, Sineresis and Total LAB.

Based on the results and discussion that the use of honey by $12 \%$ can increase the value and produce the best $\mathrm{pH}$, syneresis and total lactic acid bacteria in synbiotic yogurt.

Keywords: Sinbiotic Yogurt, Honey, pH, Sinresis, LAB.

\section{PENDAHULUAN}

\section{Meningkatnya kesadaran konsumen} atas kesehatan yang lebih baik mendorong terjadinya tuntutan konsumsi akan produkproduk bermanfaat bagi kesehatan. Salah satu pangan yang baik dan dikenal oleh masyarakat dengan pangan fungsional adalah yoghurt. Yoghurt merupakan salah satu produk hasil fermentasi susu dengan menggunakan starter bakteri asam laktat. Secara umum dalam pembuatan yoghurt digunakan bakteri Streptococcus thermophilus dan Lactobacillus bulgaricus, dan guna meningkatkan nilai tambah yoghurt ditambahkan bakteri probiotik. Probiotik adalah mikroorganisme hidup dan bila dikonsumsi dalam jumlah cukup akan memberi manfaat bagi kesehatan inangnya.
Pada pembuatan yoghurt umumnya digunakan sukrosa, selain sebagai sumber energi pada bakteri asam laktat, sukrosa juga dapat meningkatkan rasa pada yoghurt. Penggunaan sukrosa dalam yoghurt dapat mempengaruhi total BAL (Bakteri Asam Laktat) dan akan berpengaruh terhadap $\mathrm{pH}$ dan sineresis pada yoghurt. Penggunaan sukrosa atau gula dalam pembuatan yoghurt dimaksudkan sebagai sumber energi bagi pertumbuhan bakteri asam laktat yang digunakan. Penggunaan glukosa atau sukrosa pada bakteri asam laktat adalah sebesar $30 \%$ dan sisanya akan menghasilkan rasa pada yoghurt, akan tetapi gula yang berlebihan pada pembuatan yoghurt akan memberi dampak negatif pada konsumen yang menkonsumsinya terutama yang punya penyakit tertentu dan juga mempengaruhi atau menghambat pertumbuhan bakteri asam laktat.

Selain sukrosa atau gula, madu merupakan salah satu sumber energi untuk pertumbuhan bakteri asam laktat pada pembuatan yoghurt dikarenakan salah satu oligosakarida yang dapat digunakan sebagai sumber prebiotik. Kandungan terbesar pada madu adalah fruktosa $41 \%$, glukosa $35 \%$, sukrosa $1,9 \%$ vitamin A, B1, B2, B3, B4, B5, B6, C, D, E, K (Finarsih, 2014). Komponen lain dari madu yaitu oligosakarida, mineral, senyawa fenolik, enzim dan air (Matute et al., 2010). Madu 
merupakan salah satu sumber gula yang dapat dijadikan sebagai sumber energi bagi bakteri asam laktat.

Penggunaan madu dimaksudkan untuk meningkatkan nilai tambah pada yoghurt karena madu merupakan sumber prebiotik dan juga dari segi kesehatan mempunyai manfaat positif. Penggunaan madu akan mempengaruhi viabilitas bakteri asam laktat, $\mathrm{pH}$ dan sineresis yoghurt yang dihasilkan. Prebiotik adalah subtrat yang dapat difermentasi selektif oleh beberapa mikroflora kolon dimana dapat menstimulasi pertumbuhan dan meningkatkan aktivitas bakteri yang bermanfaat untuk kesehatan inangnya.

Berdasarkan uraian diatas, maka telah dilakukan penelitian bertujuan untuk mengetahui penggunaan madu terhadap nilai $\mathrm{pH}$,sineresis, dan total bakteri asam lakat

\section{MATERI DAN METODE PENELITIAN}

Penelitian ini telah dilaksanakan pada tanggal 7 Februari 2019 sampai dengan 12 Maret 2019 di Laboratorium Teknologi Hasil Ternak Fakultas Peternakan Universitas Sam Ratulangi Manado.

Bahan yang digunakan dalam penelitian ini adalah susu ultra high temperatur (UHT) sebanyak 4 L, skim milk sebanyak $400 \mathrm{~g}$, madu $240 \mathrm{~mL}$ sebagai sumber prebiotik, probiotik dari Lactobacillus acidophilus, Lactobacillus bulgaricus dan Streptococcus thermophillus. Bahan yang digunakan dalam analisa ini adalah aquades, alcohol $70 \%$, media MRS, pepton water, spritus dan MRS agar.

Peralatan yang digunakan selama penelitian antara lain autoclave, $\mathrm{pH}$ meter, Erlenmeyer, tabung reaksi, pipet, thermometer, timbangan analitik, cawan petri, desikator, blender, oven, incubator, plastic, pipet mikro, buret, lampu spritus, gelas piala, aluminium foil, tissue, handskun/sarung tangan steril dan lemari pendingin.

Rancangan percobaan yang digunakan pada penelitian ini adalah metode Rancangan Acak Lengkap (RAL) dengan perlakuan $5 \times 4$ sebagai konsentrasi madu (Steel dan Torrie, 1991), dan jenis madu yang digunakan dalam penelitian ini adalah madu asli.

Konsentrasi madu yang digunakan :

$\mathrm{P} 0=$ Kontrol/tanpa madu

$\mathrm{P} 1=$ Penambahan madu 3\%

$\mathrm{P} 2=$ Penambahan madu 6\%

P3 = Penambahan madu 9\%

P4 = Penambahan madu 12\%

Variabel yang diamati pada penelitian ini :

a. Nilai $\mathrm{pH}$ 

b. Sineresis
c. Total Bakteri Asam Laktat

\section{Prosedur Penelitian}

1. Sterilisasi Alat

Sebelum penelitian dilakukan

sterilisasi semua alat-alat yang digunakan

(tabung reaksi, Erlenmeyer, dan alat-alat lain yang digunakan).

2. Pembuatan Kultur Starter (Yelnetty dan Tamasoleng, 2019)

$$
\text { Pembuatan starter yakni }
$$
menggunakan skim milk $8 \%$ ditambahkan sukrosa $1 \%$, aquades $200 \mathrm{ml}$, disterilisasi pada suhu $115^{\circ} \mathrm{C}$ selama 15 menit, kemudian dinginkan sampai temperature $40^{\circ} \mathrm{C}$. Kemudian siapkan masing-masing wadah untuk pembuatan ketiga starter, inokulasi dengan bakteri asam laktat yang digunakan (S. thermophillus, L.bulgaricus, dan L. acidophilus) masing-masing sebanyak 3\%, setelah itu diinkubasi pada suhu $36^{\circ} \mathrm{C}$ selama 16 jam. Untuk lebih jelas dapat lihat pada Gambar 1.

3. Pembuatan Yoghurt Sinbiotik (Yelnetty et al., 2013)

Pembuatan yoghurt sinbiotik dilakukan dengan menggunakan susu UHT. Masing-masing perlakuan menggunakan susu UHT sebanyak $200 \mathrm{~mL}$ ditambahkan dengan susu skim $8 \%$, lalu homogenisasi selama 15 menit, kemudian pasteurisasi

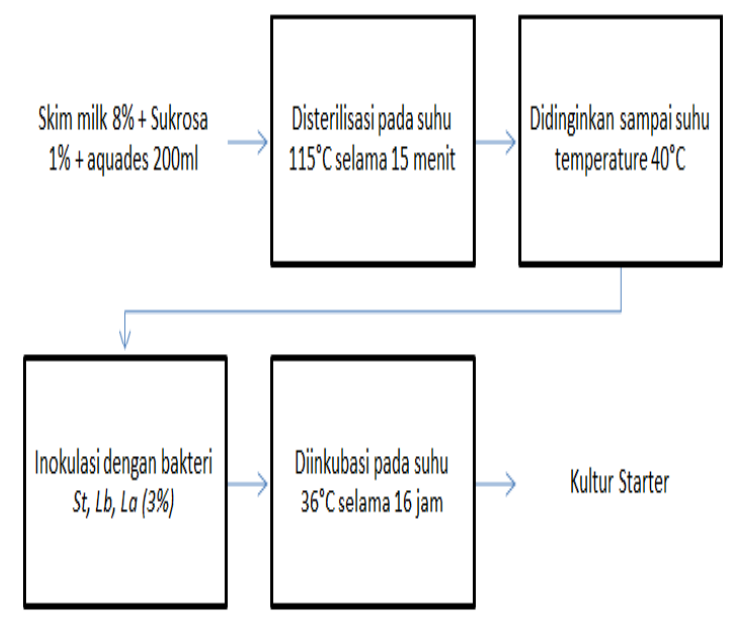

Gambar 1 : Diagram Alir Pembuatan Kultur Starter Bakteri Asalm Laktat

pada temperature $85^{\circ} \mathrm{C}$ selama 15 menit, setelah proses pasteurisasi dan sampel dalam keadaan hangat ditambahkan madu sesuai perlakuan dengan tujuan melarutkan madu, selanjutnya di salin kewadah yang telah disediakan dan lakukan pendinginan sampai temperature $40^{\circ} \mathrm{C}$. Selanjutnya diinokulasi dengan starter yang telah disiapkan terlebih dahulu dengan masingmasing starter sebanyak 3\% dengan perbandingan antara Streptococcus thermophillus, Lactobacillus bulgaricus dan Lactobacillus acidhophillus 1:1:1. Inkubasi dalam inkubator pada temperature $43^{\circ} \mathrm{C}$ Selama 6 jam. Untuk lebih jelas proses pembuatan yoghurt dapat dilihat pada Gambar 2.

4. Dipisahkan cairan dari endapan yoghurt, kemudian ditimbang endapan dalam tabung. 


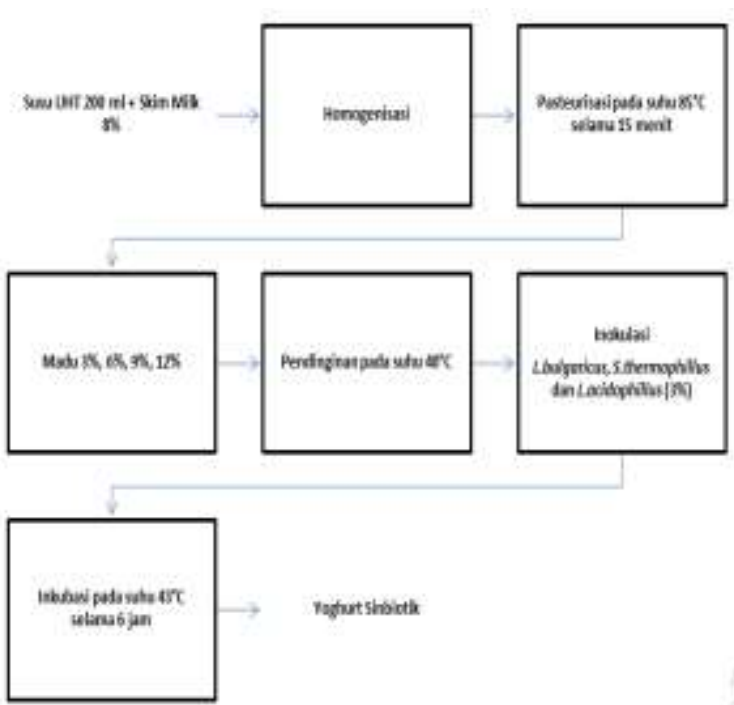

Gambar 2 : Diagram Alir Proses Pembuatan Yoghurt Sinbiotik

\section{Prosedur Analisis}

\section{pH (AOAC, 1995)}

Pengukuran $\mathrm{pH}$ dilakukan dengan menggunakan $\mathrm{pH}$ meter. Alat $\mathrm{pH}$ meter distandarisasi terlebih dahulu dengan buffer untuk $\mathrm{pH} 4$ dan $\mathrm{pH} 7$ sesuai kisaran $\mathrm{pH}$ yoghurt. Pengukuran dilakukan dengan mencelupkan elektroda $\mathrm{pH}$ meter ke dalam $10 \mathrm{~mL}$ sampel (AOAC, 1995).

\section{Sineresis (Fennema, 1996)}

Prosedur penentuan sineresis adalah sebagai berikut :

1. Tabung sentrifuge dan sampel ditimbang.

2. Dimasukan kedalam alat sentrifuge selama 20 menit dengan kecepatan $1535 \mathrm{rpm}$

$$
\text { Sineresis }=\frac{A-B}{A} \times 100 \%
$$

Keterangan :

$$
\begin{aligned}
A= & \text { Berat awal sampel sebelum } \\
& \text { disentrifuge }(\text { gram }) \\
B= & \text { Berat sesudah sampel setelah } \\
& \text { disentrifuge }(\text { gram })
\end{aligned}
$$

\section{Total BAL (Yelnetty dan Tamasoleng, 2019)}

Sebelum menghitung total bakteri asam laktat dengan metode total Plate Count (TPC) terlebih dahulu alat - alat yang digunakan disterilkan dalam auto clave pada suhu $121^{\circ} \mathrm{C}$ selama 30 menit. Tabung reaksi $1 \mathrm{~s} / \mathrm{d} 8$ yang dilabeli $10^{-1} \mathrm{~s} / \mathrm{d}$ $10^{-8}$ dan masing-masing cawan petri dengan nilai pengecernya diberi tanda. Biakan dikocok dan diambil $1 \mathrm{~mL}$, kemudian dimasukan ke dalam tabung reaksi $10^{-1}$ yang berisi $9 \mathrm{~mL}$ larutan pengecer. Tabung reaksi $10^{-1}$ dikocok sehingga bakteri tersebar dan terlepas dari rantainya, kemudian dipindahkan $1 \mathrm{~mL}$ dari tabung reaksi $10^{-1}$ ke tabung reaksi $10^{-2}$, seterusnya seperti itu sampai $10^{-8}$. Setelah selesai ambil $10^{-6}$ dan $10^{-8}$ dimasing-masing perlakuan setelah itu masukkan sebanyak 1 ml ke cawan petri yang disiapkan, Media MRS steril yang telah didinginkan (45 $47^{\circ} \mathrm{C}$ ) dituangkan ke cawan petri sebanyak kurang lebih $10 \mathrm{ml}$ dan biarkan sampai beku. Cawan petri dibalik dan dimasukkan 
kedalam incubator dengan suhu $36^{\circ} \mathrm{C}$ selama 48 jam, perhitungan jumlah mikroba dilakukan dengan menggunakan alat hitung "Hand Talky Counter". Dari jumlah koloni yang diperoleh dikalikan dengan jumlah pengeceran, hasilnya merupakan jumlah total koloni bakteri.

\section{HASIL DAN PEMBAHASAN}

Variabel pengukuran yang digunakan pada penelitian ini yaitu pengukuran nilai $\mathrm{pH}$, Sineresis dan Total Bakteri Asam Laktat (BAL). Hasil analisis yoghurt sinbiotik dapat dilihat pada Tabel 1

\section{Nilai pH Yoghurt Sinbiotik}

Pada Tabel 1, nilai $\mathrm{pH}$ yoghurt sinbiotik dengan penggunan madu, rataan nilai $\mathrm{pH}$ yang diperoleh berkisar antara 4,90 - 5,37. Rataan nilai $\mathrm{pH}$ terendah pada P2(6\%) sebesar 4,95 dan rataan nilai tertinggi ada pada $\mathrm{P} 0(0 \%)$ sebagai kontrol sebesar 5,37.

Terjadinya penurunan $\mathrm{pH}$ setelah penambahan konsentrasi madu pada pembuatan yoghurt sinbiotik dikarenakan terpenuhinya sumber karbohidrat yang ada pada madu yang disebabkan oleh bakteri yang terdapat pada yoghurt dimana bakteri tersebut dapat mengurai laktosa (gula) yang ada pada susu menjadi asam laktat dan pertumbuhan dalam karbohidrat dapat menurunkan $\mathrm{pH}$ media hingga 3,5-5,0 (Tatang dan Wardah, 2013). Menurut Nofrianty et al. (2013), bakteri asam laktat pada umumnya menghasilkan sejumlah besar asam laktat dari fermentasi subtract energi karbohidrat. Asam laktat yang dihasilkan dari metabolisme karbohidarat akan menurunkan nilai $\mathrm{pH}$ lingkungan pertumbuhannya dan menimbulkan rasa asam. Djaafar dan Rahayu (2006) menyatakan bahwa selama proses fermentasi BAL akan memanfaatkan karbohidrat yang ada hingga terbentuk asam laktat, hingga terjadi penurunan nilai $\mathrm{pH}$ dan peningkatan keasaman

\section{Nilai Sineresis Yoghurt Sinbiotik}

Hasil analisa sineresis yoghurt menunjukkan bahwa sineresis pada yoghurt mengalami penurunan, sineresis tertinggi berada pada $\mathrm{P} 0 \quad(0 \%)$ dengan tanpa perlakuan madu sebesar 48,850 dan sineresis terendah terdapat pada konsentrasi madu P4 (12\%) yaitu sebesar 44,025 dapat dilihat pada Tabel 1.

Penurunan nilai sineresis terjadi seiring dengan meningkatnya konsentrasi madu. Hal ini dapat dijelaskan bahwa peningkatan konsentrasi madu menyebabkan meningkatnya kapasitas 
Tabel 1. Rataan Nilai pH, Sineresis, dan Total Bakteri Asam Laktat

\begin{tabular}{lccccc}
\hline \multirow{2}{*}{ Variabel } & \multicolumn{5}{c}{ Perlakuan } \\
\cline { 2 - 6 } & P0 & P1 & P2 & P3 & P4 \\
& $0 \%$ & $3 \%$ & $6 \%$ & $9 \%$ & $12 \%$ \\
\hline pH & $5,38^{\mathrm{a}}$ & $5,13^{\mathrm{ab}}$ & $4,90^{\mathrm{b}}$ & $5,00^{\mathrm{b}}$ & $5,00^{\mathrm{b}}$ \\
Sineresis $(\%)$ & $48,85^{\mathrm{a}}$ & $47,97^{\mathrm{a}}$ & $46,78^{\mathrm{ab}}$ & $45,2^{\mathrm{bc}}$ & $44,0^{\mathrm{c}}$ \\
Total BAL $(\mathrm{cfu} / \mathrm{mL})$ & $7,812^{\mathrm{a}}$ & $7,856^{\mathrm{ab}}$ & $7,889^{\mathrm{ab}}$ & $8,078^{\mathrm{bc}}$ & $8,178^{\mathrm{c}}$ \\
\hline
\end{tabular}

Keterangan : Superskrip yang berbeda pada baris yang sama artinya berbeda sangat nyata $(\mathrm{P}<0,01)$

pengikat air. Hal ini sesuai dengan pendapat Goncalves et al. (2005), yang menyatakan bahwa penambahan konsentrasi pengental akan mengurangi terjadinya sineresis secara signifikan, yang artinya viskositasnya (kekentalan) meningkat. Terjadinya penurunan nilai sineresis tersebut juga dikarenakan pada saat fermentasi terjadi penggumpalan protein karena asam laktat yang dihasilkan oleh bakteri Streptococcus thermophillus dan Lactobacillus bulgaricus, sehingga produk tersebut menjadi kental. Hal ini didukung oleh Winarno dan Fernandez (2007) yang mengatakan bahwa pembuatan yoghurt merupakan proses fermentasi dari gula susu (laktosa) menjadi asam laktat yang menyebabkan tekstur yoghurt menjadi kental dimana sineresis dapat tekan. Selain itu, Burhan (2008) juga mengatakan bahwa kondisi asam menyebabkan protein susu yaitu casein berubah struktur dan terdenaturasi membentuk gumpalan.

\section{Total Bakteri Asam Laktat}

Rataan total bakteri asam laktat pada penelitian ini untuk pengaruh penambahan madu berkisar antara 7,812 sampai 8,178 (Log cfu/mL). Rataan total bakteri asam laktat terendah diperoleh dari P0 (0\%) sebagai kontrol sebesar 7,812 sedangkan rataan total bakteri asam laktat tertinggi diperoleh dari P4 (12\%) yaitu sebesar 8,178.

Pada Tabel 1 terlihat bahwa total bakteri asam laktat yang dihasilkan berkisar antara $10^{7}$ dan $10^{8}$, jumlah tersebut masih memenuhi standar yang ditentukan Badan Standar Nasional, SNI 2981 : 2009, yang mensyaratkan minimal sebesar $10^{7}$ sel bakteri probiotik. Proses pertumbuhan bakteri Starter dalam pembuatan yoghurt diawali dengan peningkatan laju pertumbuhan $S$. thermophillus yang memproduksi asam laktat pada $\mathrm{pH}$ rendah untuk mengoptimalkan pertumbuhan $L$. acidophilus dan L. bulgaricus memproduksi asam laktat yang menimbulkan penurunan $\mathrm{pH}$ (Messens dan Vugst, 2002). Hal tersebut karena kandungan terbesar pada madu adalah 
fruktosa dan glukosa. Komponen lainnya yaitu oligosakarida, mineral, senyawa fenolik, enzim dan air (Matute et al., 2010). Untuk starter $S$. thermophilus memiliki sifat menyukai suasana mendekati $\mathrm{pH}$ 6,5. Starter ini dapat menstimulasi pertumbuhan dari starter lain dengan mensintesis asam format (Senditya et al, 2014). Dengan meningkatnya jumlah populasi mikroba maka aktivitas metabolismenya juga akan meningkat (Bahow et al, 2016).

\section{KESIMPULAN}

Berdasarkan hasil dan pembahasan bahwa dengan penggunaan madu sebesar $12 \%$ dapat meningkatkan nilai serta menghasilkan $\mathrm{pH}$, sineresis dan total bakteri asam laktat terbaik pada yoghurt sinbiotik.

\section{DAFTAR PUSTAKA}

Association of Official Analitycal Chemist. 1995. Official Methods of Analisys Chemist. 85(5): 1187-1200.

Badan Standarisasi Nasional. 2009. SNI Yoghurt (SNI 01-2981-2009). Dewan Standar Indonesia, Jakarta.

Bahow, G., A. Yelnnety, M. Tamasoleng dan W.J.H. Pontoh 2016. Karakteristik es krim menggunakan starter bakteri probiotik Streptococcus thermophillus dan
Lactobacillus acidophilus. Jurnal Zootek 36(1): 69-76.

Burhan, B. 2008 Kefir Minuman Susu Fermentasi dengan Gudang Khasiat Untuk Kesehatan. Penerbit PT Gramedia Pustaka Utama, Jakarta.

Djaafar, T. F dan E. S. Rahayu. 2006. Karakteristik yogurt dengan inokulum Lactobacillus yang diisolasi dari makanan fermentasi tradisional. Jurnal. Agros 8(1): 73-80.

Fennema, O. R. 1996. Principles of Food Science Part 1. Food Chemistry Incorporation, New York.

Goncalves, D., C. Perez, G. Reolon, N. Segura, P. Lema, A. Gambaro, P. Varela, dan G. Ares. 2005. Effect of thickener on the texcture of stirred yoghurt. Alim. Nutr. Araraquara 16(3): 207-211.

Matute, R. A. I., M. Brokl, A.C. Soria, M.L Sanz, dan Matinez-Castro. 2010. Journal Gas Chromatographic-mass spectrometric characterisation of triand tetrasaccharides in honey. Food Chem 120(2): 637-642.

Messens, W dan L. De Vugst. 2002. Inhibitory substance produced by Lactobacilli isolated from Sourdougs- a revue. Intl. journal of Food Microbiology 72(2): 31-43.

Nofrianty, R., F. Ajima, R. Elyasmi, 2013. Pengaruh penambahan madu terhadap mutu yoghurt jagung. Jurnal Aplikasi Teknologi Pangan 2(2): 6067.

Senditya, M., M. S. Hadi, T.E. Estiati. 2014. Efek Probiotik dan Sinbiotik Simplisia Daun Cincau Hitam (Mesona palustris BL). Jurnal Pangan dan Agroindustri 2(3): 141-151.

Steel, R. G. D. H. Torrie. 1991. Prinsip dan Prosedur Statistika. PT. Gramedia 
Pustaka Utama, Jakarta.

(Diterjemahkan oleh B. Sumarti).

Tatang, S dan Wardah. 2013. Mikrobiologi Pangan teori dan praktik. ANDI, Yogyakarta.

Tamime, A. dan R. K. Robinson. 1999. Yogurt: Science and Technology. 2nd Edition. Woodhead Publishing, Ltd Cambridge. England.

Winarno, F. G dan I. E. Fernadez. 2007. Susu dan produk fermentasinya. MBrio Press. Bogor.

Yelnetty, A., R. Hadju, M. Tamasoleng dan I. Wahyuni. 2013. Pengaruh Pemberian Minuman Advokad Fermentasi Terhadap Pertambahan Berat Badan, Total kolesterol dan kadar Urease Dalam darah Tikus Putih Jenis Wistar. Jurnal Zootek 33(1): 38-44.

Yelnetty, A dan M. Tamasoleng. 2019. The addition of Yam Tuber (Dioscorea alata) flour as a source of prebiotic on biomilk synbiotic characteristics IOP Conf. Ser.: Earth Environ. Sci. 247: 012-052. 